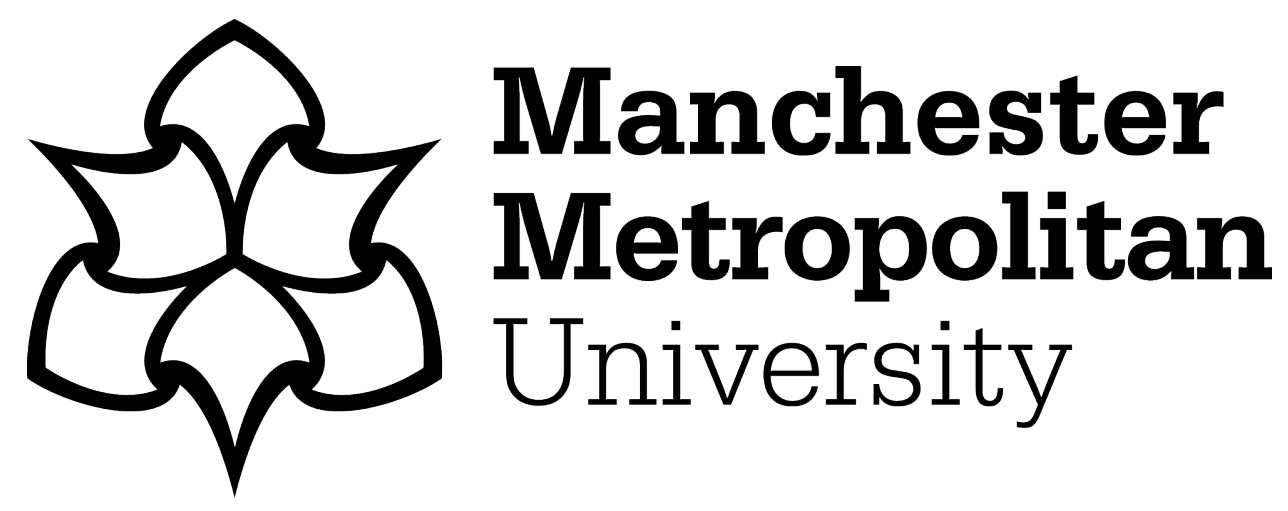

Edensor, Tim and Millington, SD (2018) Spaces of Vernacular Creativity Reconsidered. In: Creative Placemaking: Research, Theory and Practice. Routledge Studies in Human Geography . Routledge, London. ISBN 9781138098022 (In Press)

Downloaded from: https://e-space.mmu.ac.uk/620577/

Version: Accepted Version

Publisher: Routledge

Please cite the published version 


\title{
Spaces of Vernacular Creativity Reconsidered
}

\section{Tim Edensor and Steve Millington, Manchester Metropolitan University}

\begin{abstract}
Our edited volume, Space of Vernacular Creativity: Rethinking the Cultural Economy (2009) critically responded to the preoccupations that had dominated writing on creative place-making. In this chapter, we focus on the book's key imperatives: to decentre instrumental and reductive conceptions about the location of creativity that were oriented around dominant notions of the 'creative economy', and interrogate how alternatively, creativity might be far more expansively conceived. We identify what remains salient in our original arguments, which areas of creative place-making we ignored and underplayed, and key contributions that have advanced thinking about creative geographies since the book's publication.
\end{abstract}

In Space of Vernacular Creativity, we sought to extend understandings beyond the narrow prescriptions of culture-led regeneration and the normative framework established in economic geography to identify cultural clusters (Mommaas, 2004), and explore creativity in a broader sense, focusing on the relationship between creativity and place, and how creativity could be generative of non-economic values. We wanted to provide a more constructive riposte to the many critiques of the 'creative city' and the 'creative class' script popularised by Richard Florida (2002) and Charles Landry (2000), to uncover practices that stood in opposition to the alignment of creativity with the cool, sophisticated and metropolitan. We asked that if there is a creative class, then who might be the uncreative classes against whom they are implicitly constructed? And if there are cool places to which this creative class gravitate, then what does this mean for all those other places that fail to make the cut on creativity indices? Instead, we wanted to embrace abject, marginal, un-sexy and less-than glamorous unspectacular creative practices and reveal their role in enhancing the lives of people in everyday spaces, to offer a more powerful and inclusive analysis of creativity and place.

As we entered the $21^{\text {st }}$ Century, creativity occupied an elevated position in governmental policy responses to the economic and political challenges of the day. In UK, for instance, Cool Britannia captured a sense of optimism that somehow, through the proliferation of arts and cultural districts, festivals and music scenes, our cities and national economy could be reinvented. Richard Florida's contentions were conceived as providing the academic authority that supported such aims, and whatever the criticism of his key ideas and methods, we cannot ignore Florida's influence on urban policy and civic leaders around the world in embedding the notion that the creative 
class can drive economic regeneration. At the time we compiled the book, this seductive narrative has begun to fade from policy discourses following the 2008 financial crash. Priorities shifted under austerity. Arguments to maintain public subsidy for arts and culture have become marginalised in the face of calls to protect frontline services or tackle homelessness. Florida's (2017) recent tacit admission that the creative class were perhaps nothing more than this generation's gentrifiers further signifies that optimism about their central economic role is over. Nevertheless, the cultural life of places persists, by any means necessary. As arts professionals scrabble for ever reduced grants, volunteers and community-led action are becoming more significant agents within the local cultural landscape. At the same time, ideas such as Lydon and Garcia's Tactical Urbanism (2015) have come to the fore in the absence of both public and private investment. Through a make-do attitude and experimentation, tactical place-making interventions led by local communities have undermined the strategic thinking which underpinned the creative city script, and seem to underscore the importance of the vernacular that we highlighted.

The first key emphasis in Space of Vernacular Creativity, as is explicit in its title, was to embark on a thorough decentering of geographies of creativity by moving towards the multiciplicity of creative practices that take place elsewhere, in other sites and networks through which creative ideas and skills are produced and circulated. The overwhelming focus on the city and the city centre, implicitly conceived as the domain of the creative class, the realm in which they work, play and consume, or the arts districts and cultural quarters that they fashion, has marginalized other spaces in which creative practices take place. Less glamourous parts of the city - suburbs, those areas of Victorian and Edwardian terraced housing which remain resistant to gentrification, and modernist housing schemes - were identified as less trendy or more sedate, while smaller industrial or post-industrial urban settings, market towns, villages and rural areas were largely consigned to the dominion of the irredeemably uncool and uncreative. These areas were drastically neglected while the apparently global cities of London, Berlin and New York, and smaller regional cities such as Manchester and San Francisco were regarded as founts of creativity, sites where a critical mass of creatives inspired each other and consumed each other's goods and services. While galleries, coffee shops and loft studios were celebrated as sites of creativity, living rooms, sheds, garages, gardens and community centres were not. In attempting to address these geographical distortions, chapters in the book examine creative practices that take place in mundane domestic settings located in the suburbs of Toronto, the working-class estates of Sheffield, Australian country towns, and community gardens in northern England.

Since then, other work has consolidated this move away from those sites exclusively identified as urban hot spots of creativity. Waitt and Gibson (2013) have detailed how unfashionable, provincial, co-operative art spaces can reinforce place-belonging, and Michele Lobo (2017) strikingly describes how the unpromising setting of a disused underground suburban car park in Darwen, Australia, has become a convivial venue 
for the shared, varied creative practices of marginalised Aboriginal woman and migrants. Here, friendships have emerged through shared creative production as unexpected connections have been forged between participants within an immersive, inclusive atmosphere. More domestic spaces have been the focus of work by Louise Platt (2017) and Fiona Hackney (2013), who consider how women's quotidian, mundane creative practices of knitting and crocheting act to craft identities and contribute to placemaking. Besides reappraising the ways in which evaluations around creativity have marginalised certain highly gendered activities, their analyses emphasise how creative production extends across the familiar realms of home and community, an arena of creativity that we somewhat neglected in Spaces of Vernacular Creativity. In reinforcing the creativity that inheres such domestic spaces, Jessica Lee (2010) concentrates on the more mundane practices of bed-making, cooking, tidying up and even scrubbing floors to are sensual, memory filled and imaginative creative practices of homemaking. For Lee, the aesthetic effects of such daily tasks do not merely revolve around making judgements but by the 'the small pleasure afforded by the simple awareness and presence of mind during our everyday lives', and are particularly well exemplified by the traditional practice of laundryhanging discussed by Rautio (2009) which thoroughly entangles creative imagination, memory borne of habit and multi-sensory immersion in the job at hand.

In Spaces of Vernacular Creativity, in exploring emergent forms of shared production across the photosharing Flickr network, Jean Burgess showed how cyberspace was also a neglected realm of creativity, an arena in which connections around creative making were vastly extended. These new media applications have subsequently multiplied with the increasing popularity of geocaching, game-playing, creative writing, video-making and the proliferation of memes. Burgess has continued to mine this area, showing that though they may be mimicked in developing commercial strategies, viral videos promote inventive adaptive engagement from a wide variety of participants, and subsequently a 'flurry of parodies, mash-ups and remixes' (2016: 90) that exemplify the ongoing production of vernacular network creativities. Through such social networks, the boundaries between professionals and enthusiasts can become blurred, with some non-professional participants becoming widely renowned. Similarly, Vasquez and Creel (2017) highlight the imaginative 'chats' that produce a shared conviviality amongst the online community, who use Tumblr blogs. In addition, in drawing upon the phenomenon of crowdsourced art, Literat and Glăveanu (2016) exemplify how the internet has enormous potential to foster a distributed creativity grounded in collaborative communication and interaction that is available for the participation of anybody who wishes to contribute. They contend that the sheer diversity of the knowledge, skills and cultural resources of these multiple participants generates a context in which creative possibilities proliferate.

Despite the abundant evidence that creative practice is much more widely distributed, reductive, elitist notions of what constitutes creativity can have profound political effects upon cultural endeavours that take place away from metropolitan taste-makers. 
Abigail Gilmore (2013) further explores how participatory arts policy-makers and fundng bodies routinely ignore local forms of creative practices that do not accord with those they esteem, and as Miles and Ebrey (2017) argue, marginalization and lack of support from central and local governments, cultural institutions and the private sector for smaller, non-urban settings can entrench economic decline and stagnation.

In examining the geographical focus of our 2009 volume, we too were culpable of neglecting to identify and discuss creative practices in plethora of settings. Though such an exhaustive task is beyond any one text, perhaps we should have made more extensive efforts to account for non-western forms of creativity. In considering the extraordinary creative adaptations, improvisations and in fashioning urban lives and livelihoods in African, South American and Asian cities that have been explored by many writers. Indeed, as Jenny Robinson (2006: 4) claims, an understanding of the vitality of such urban cultures without considering 'a strong sense of the creativity of cities' truncates the potential for imagining their futures.

Such an exploration, amongst many other accounts, could include references to the extraordinary creation of Chandigarh's Rock Garden, now a global tourist attraction, by Nek Chand, an 'outsider artist' who assembled a range of figural sculptures from the debris of demolished buildings (Jackson, 2002), the incredibly adaptive, improvisatory extensive trading networks established by peddlers belonging to Senegal's Murid Brotherhood (Diouf and Rendall, 2000), or the hybrid architecture of Hong Kong (Abbas, 2002) and improvisational entrepreneurial tactics and fleetingly assembled structures of Lagosians (Hecker, 2010). It might also investigate the ongoing fashioning of the anti-colonial, anti-neoliberal practice of buen vivir (good living for all) in Latin America (Escobar, 2010), the ever-transforming streetscapes of Indian cities that are endlessly recomposed out of recycled materials and temporarily occupied by a multitude of actors (Mehrotra, 2008), the critical political performances of Lima's street comedians (Vich 2004), and the ongoing assemblage of informal shack dwellings in Sao Paulo's informal settlement, Paraisópolis (McFarlane, 2011). On the other hand, many urban theorists from China have eagerly grasped the creative city concept and continued the normative research agenda established in the West in analysing networks and clusters of creative businesses (for example, see Cho et al, 2018).

This brings us onto a second and related key aim of Spaces of Vernacular Creativity, which was to interrogate how creativity might be more expansively conceived: to escape from a rather instrumental and reductive understanding that had emerged as part of discussions about the 'creative economy' and the 'cultural industries', a conception that found great favour amongst city managers and economic strategists. Our attention, therefore, was drawn towards vernacular forms of creative endeavour amongst alternative and marginal groups, as well as cultural producers who create non-economic outcomes. In moving beyond a narrow focus on taste and aesthetics, we sought to recognise how creativity may also produce social collaboration and communication. 
The premium placed on promoting creativity became inextricably entangled with the much-vaunted championing of what Richard Florida called the 'creative class', a group conceived as essential to the regeneration of cities that had suffered significant industrial decline. These artists, gallery owners, baristas, fashion designers, advertisers and musicians were conceived as being able to reignite an economic spark by developing cultural industries and thereby attracting new inhabitants with high disposable incomes who were lured by the promise of trendy urban environments and lifestyle accoutrements. Evidently, this depiction of a particular group of people who collectively constituted a creative class was exclusive, ruling out those who pursued creativity in less circumscribed ways. Recently, the orbit of those belonging to the creative class has expanded to incorporate those from the traditional professions of barbering and bartending who, under conditions of gentrification, are being revalued in way that recognise the creative elements that they always practised (Ocejo, 2012). Nevertheless, the durable if fluid construct of the creative class continues to perpetrate a limited notion about who and what is 'creative'. Thus, the value of creativity often remains tethered to its capacity to make profits and conforms to the entrepreneurial imperatives of city managers, reinforcing the strategic role of creative industries in economic development and urban renewal. According to such a perspective, creative production and practice, especially insofar as it involves the provision of fashion, food, culture and arts, is as integral to the promotion of the city as tolerance for social and cultural diversity.

Reductive and reified conceptions also resonate in those assertions that creativity can primarily be defined in terms of aesthetic experimentation or 'innovation'; that is, in the original work of artists, poets and musicians. Our thesis in Spaces of Vernacular Creativity was that these debates have produced highly restricted understandings about who is creative, what can be considered as a creative product or practice, and where it is that creativity takes place. We drew upon the important arguments of Hallam and Ingold (2007) to contend that creative practice can be habitual and reiterative, is necessarily adaptive and improvisational and is equally likely to be found in collective work than individual artistic innovation. Moreover, we insisted that creativity did not need to be identified by experts - including the growing host of cultural intermediaries and media presenters - and in fact where this took place, was principally illustrative of the habitus and dispositions of those who espoused such particular tastes. These arguments have been subsequently reinforced by alternative, much more inclusive definitions such as that articulated by Waitt and Gibson who maintain that creativity is 'a field of choices and possibilities that are set up in the tensions between being and becoming' (2013: 75). Such tensions proliferate through social life.

One central argument in the book focused on foregrounding the qualities of vernacular and everyday creativity. All too often, such endeavours are maligned by arguments based on class-oriented values that champion certain forms of creative production in contradistinction to those that are not judged to be 'cool', sophisticated or fashionable. By contrast, we wanted to honour the non-economic values and outcomes produced 
by alternative, quotidian, diverse and more socially inclusive creative practices, and in this spirit, chapters discussed Elvis festival situated in a small, rural Australian town (Gibson, 2009), the amusing and diverse uses of garden gnomes (Potts, 2009) and the seasonal practice of garbing the outside of houses with Christmas lights (Edensor and Millington, 2009). Such practices were community-oriented and emerged in mundane settings, and were certainly not examples of top-down urban provision.

Happily, a plethora of academic accounts about other mundane, vernacular and everyday skilled practices have emerged since the book was published. This has coincided with an upsurge in work on geographies of making and crafting (Hawkins and Price, 2018) that also honours both artistic endeavour and more vernacular, collective practices. Such accounts have foregrounded the creativity and communality that inheres in the everyday practices of hairdressing (Holmes, 2015), knitting (Price, 2015) and customising cars (Warren and Gibson, 2011) as well as the craft expressed in dry stone-walling (Paterson, 2018), the making and curation of neon signs (DeLyser and Greenstein, 2018), the production of hand-made surfboards (Gibson and Warren, 2014) and festive lantern-making (Edensor, 2018), creative practices that move between highly-skilled work to hobbyist enthusiasms.

This inclusive shift to considering creative practices of making is also augmented in recent times by an expanded understanding of the creative economy that incorporates a range of labour practices that has surfaced through what Carr and Gibson (2016: 299) describe as 'a renaissance in small-scale making' which has especially emerged in industrial cities, in which 're-connections are being forged with themes such as quality, providence, craft, ethics, tacit design knowledge, haptic skill and the value of physical labour'. Here then, and following Hallam and Ingold's contentions, creativity was always already embedded in all forms of industrial labour; indeed, production was dependent upon the capacities of workers to adapt and acquire a sensuous knowledge of the products that they helped to forge and assemble. As these manufacturing processes have become less familiar in many deindustrialised urban settings, the skill and know-how required to make things is being revalued, tinged with a nostalgic sense of loss. Yet though the value of making has been substantively reappraised in recent times, in certain contexts, tendencies to perpetrate hoary distinctions between crafted products and practices of making remain. For instance, away from the contexts of urban industry, in exploring the reconfiguration of rural creativity, David Bell (2015) discusses how cultural intermediaries express aesthetic judgements that strongly prioritise the innovative and cutting edge over 'traditional' and customary craft items. Moreover, the primary utility of the crafts as economic resource rather as valuable in achieving broader social goals has been integral to recent neo-liberal British governmental agendas (Jakob and Thomas, 2017).

Similar kinds of negative appraisal also continue to surround creative production in other settings that are distant from metropolitan fashions. One example is at Blackpool, Britain's most popular holiday resort. Situated on the Lancashire coast and founded in the $19^{\text {th }}$ century to serve as a site for pleasure and leisure for workers in 
the industrial urban centres of Lancashire and Greater Manchester, the town has long been associated with cheap, popular and working class attractions, often caricatured as 'vulgar', 'tacky' and tasteless by supposedly more sophisticated cultural commentators. The town's illuminations, arranged along six miles of seafront, have attracted millions of visitors for over a hundred years, and yet are rarely subject to media reviews. They epitomize a local expression of vernacular creativity in a style that remains immune from wider fashions and notions of 'good taste' and coolness, sitting outside the professional and sophisticated circuits that have driven the accelerating internationalisation of metropolitan light festivals. Rather, the design of the illuminations - which are stand-alone installations, themed sections arranged between lampposts on either side of the seafront road, or large tableaux - follows a distinctly place-based vernacular based on longstanding aesthetics and craft knowhow, and is designed to satisfy the desires of visitors to experience nostalgia, conviviality and jollity (Edensor and Millington, 2013). Situated in the resort's own illuminations depot, local designers and technicians produce and stage the annual two-month extravaganza, oblivious to the tastes of metropolitan taste-makers who are unable to recognise a creative practice that is grounded in a distinctively local place identity and history not concerned to pose as fashionable and cool.

As we have emphasised, the notion of the creative economy is tied to a reductive understanding that creativity is an economic resource that can be deployed to advance urban growth. In Spaces of Vernacular Creativity we challenged this instrumental, neoliberal conception by foregrounding the more-than-economic forms of creativity that persist and the important social and cultural functions that they advance. Creativity, we argued, does not need to be connected with economic growth at all, but can be underpinned by other values such as generosity, care and reciprocity. As Waitt and Gibson claim, 'capitalist means of production are only one possible way of organising resource use and exchange, opening up possibilities to explore non-capitalist, anticapitalist, non-profit, collective, informal and socialist means of production' (2013: 77). This articulates how notions of productivity need to be defined beyond a narrow economic context, wherein the production of friendship, wellbeing and conviviality might be more extensively honoured as some of the consequences of creative practices, along with more tangible outcomes such as the strengthening of individual and collective capacities, community building and place-making. Hartley and Hargreaves (2016) declare that such non-economic outcomes might constitute the more inclusive notion of 'creative citizenship', where the potential to engage in forms of creative practice can produce convivial engagements with others that generate enduring social connections. Indeed, Louise Platt (2017) demonstrates that women's shared everyday crafting practices produces exactly these kinds of lasting friendships as well as a sense of well-being amongst participants.

In further considering more-than-economic motivations for creative practices, we can identify a range of practices that are entangled with particular political objectives and with experimenting with alternative lifestyles that move away from consumerism and 
towards social and environmental sustainability. As Harriet Hawkins claims, the aforementioned renewal of craft practices - or 'craftivism' - is frequently oriented around an avowedly political project that foregrounds an ethos of recycling, making do and mending. Gregson et al (2010) have discussed the extraordinary adaptations of materials wrenched from huge obsolete ships by Bangladeshi furniture makers and other craft workers for economic gain, innovatively refashioning industrially produced materials as part of a recycling practice that leaves little vestige of these giant vessels. At a much smaller-scale, the mundane but highly skilled practices of the host of restorers featured by Bond et al (2013) who repair clocks, bicycles, ceramic items, books, footwear, furniture and musical instrument, amongst other objects, are the remaining exponents of a world in which repair and maintenance were once a far more commonplace activity, both as household chore and paid work. And yet, it seems that such practices are once more becoming championed in context of finite resources and disposability, as the ethical implications of revaluing these practices become more apparent. Here, practices through which objects and materials are assembled and reassembled, customised, adapted, altered and restored are generating new forms of creative know-how as well as recovering lost skills.

This evolving experimental disposition towards devising alternative everyday urban lifestyles is explored by Jana Wendler (2016) who investigates how particular groups try-out more sustainable, equitable and collective ways of living in autonomous spaces temporarily carved out in the city. Such open-ended, improvisational spaces foster new imaginaries, propose different economies and develop distinct social relations in envisaging alternative futures. These experimental efforts to achieve more sustainable living practices are more radically exemplified by Canadian off-gridders who improvise ways of living in isolated situations, working out how to build houses and manage energy supply by practising forms of 'modest creativity and mundane intuition'. Such adaptive exercises emerge out of unfolding experiences of dwelling that deepen a relationship with place (Vannini and Taggart, 2014: 282).

At the same time, and has so often been the case, certain non-economically motivated creative practices that purport to challenge over-commodified and over-regulated urban environments, notably those that gather under the category of tactical urbanism, have, according to Oli Mould (2014), proved susceptible to incorporation by the very agencies that they oppose. For certain urban policy strategies, rather than seeing such creative reappropriations of urban space as illicit, have construed them as signifying coolness, as vital elements that demonstrates an area's 'vibrant' street culture. These guerrilla, participatory and pleasurable initiatives, including flash-mobbing, yarn bombing, pop up shops and guerrilla gardening. By being absorbed into urban marketing strategies in this fashion, such insurgent tactics are in danger of losing their critical potential. According to Mould, they become expected ingredients of the creative city rather than intrusive and disruptive to official governance and advertising, though perhaps Mould pessimistically overstates the extent to which all resistant practices can be incorporated in this way. As Heather McLean (2016) exemplifies, creative 
expressions of resistance and solidarity can re-emerge despite the absorption of radical creative groups into local state-led, instrumental economic strategies that aim to market their 'edginess'.

Although this suggests that the economic is frequently able to co-opt forms of resistant creativity into economic and managerial strategies, the relationships between the economic and the non-economic, and between artistic and vernacular forms of creativity, are often more complex and ambiguous than we suggested in Spaces of Vernacular Creativity. To illustrate these complexities, we draw on the example of the Moonraking Festival held bi-annually in the small West Yorkshire mill town on Slaithwaite (Edensor, 2018). 30 years since its inception, the event remains popular amongst the townsfolk. It is based on a local myth from the early $18^{\text {th }}$ century based on the illegal trade in alcohol, supplied covertly by barges on the local canal into which barrels were dropped and retrieved by men from the town. Upon being apprehended by vigilant customs officers, the men pretended to be drunk, and in that state declared that they were trying to fish the moon out of canal, thereby duping the officers. This incident of local cunning forms the basis for a lantern parade that commences at the canal basin, at which a large paper lantern in the shape of a moon is hoisted to the front of the procession, which subsequently makes its way around the village. Hundreds of the townsfolk participate in carrying illuminated lanterns fashioned in accordance with the theme that has been chosen that year. The bi-annual recurrence of the festival has generated the development of considerable local skill in lanternmaking, through the organization of workshops. Several local participants who have been steeped in the festival since childhood have become professional lanternmakers, selling their expertise in workshops organized in preparation for this festival and other events, and making high quality installations and lanterns for festive display. Here, communal, non-economic creative practice has eventuated in providing some contributors with a livelihood as makers, artists and designers.

Any reductive attempts to circumscribe the geography of creativity and delineate the kinds of activities and people that should be associated with creativity, are we believe, doomed to failure. Creativity proliferates and seethes in everyday life and in quotidian spaces; it is present in the most mundane domestic practices, in work procedures and leisure activities. It is not merely expressive of a unique individual aptitude, but can be shared and produced in convivial settings, it may reside in experimental or reiterative approaches to living, making and socialising. It most certainly cannot only be associated with entrepreneurs and artists, and is undoubtedly located in settings that are far from urban centres. This greater inclusivity is being borne out by the incorporation of a host of domestic, craft, industrial, artistic, communal and traditional practices into accounts that are widening the scope of what we might consider creative. We welcome the rejection of creativity as intrinsically economic, urban and singularly individualistic, claims that have been greatly expanded by scholars since the publication of Spaces of Vernacular Creativity. We anticipate that elitist, classridden definitions will be more widely rejected, recognised as signifying banal efforts 
to acquire cultural capital and status, and the protean nature of creativity will become ever more apparent.

\section{Acknowledgements}

Thanks to Cara Courage and Anita McKeown for their supportive, critical and patient support, and to Talia Melic for reading an earlier draft of this chapter

\section{References}

Abbas, A. (2002) 'Cosmopolitan de-scriptions: Shanghai and Hong Kong', in C.Breckenridge, S.Pollock, H.Bhabha and D. Chakrabarty (eds) Cosmopolitanism, Durham NC: Duke

Bell, D. (2015) 'Cottage economy', in Oakley, K. and O'Connor, J. eds., The Routledge Companion to the Cultural Industries. London: Routledge, pp. 222-231.

Bond, P. DeSilvey, C. and C., Ryan, J. (2013) Visible Mending: Everyday Repairs in the South West. Axminster: Uniformbooks.

Burgess, J. (2014) 'All your Chocolate Rain are belong to us?' viral video, you tube and the dynamics of participatory culture', in N. Papastergiadis and V. Lynn (eds) Art in the Global Present. UTSe Press, Sydney, pp. 86-96.

Carr, C. and Gibson, C. (2016) 'Geographies of making: Rethinking materials and skills for volatile futures', Progress in Human Geography, 40(3): 297-315.

Cho, R. Liu, J. and Ho, M (2018) 'What are the concerns? Looking back on 15 years of research in cultural and creative industries', International Journal of Cultural Policy 24(1): 25-44.

Diouf, M. and Rendall, S. (2000) 'The Senegalese Murid trade diaspora and the making of a vernacular cosmopolitanism' Public Culture, 12(3): 679-702.

Edensor, T. (2018) 'Moonraking: Making things, place and event', in L. Price and H. Hawkins (eds) Geographies of Making / Making Geographies: Embodiment, Matter and Practice, London: Routledge

Edensor, T. and Millington, S. (2013) 'Blackpool Illuminations: revaluing local cultural production, situated creativity and working-class values', International Journal of Cultural Policy, 19(2): 145-161.

Edensor, T., Leslie, D., Millington, S. and Rantisi, N. (eds) (2009) Spaces of Vernacular Creativity: Rethinking the Cultural Economy. London: Routledge.

Escobar, A. (2010) 'Latin America at a crossroads', Cultural Studies, 24(1): 1-65. 
Florida, R. (2002) The Rise of the Creative Class: And How it's Transforming Work, Leisure, Community and Everyday Life, New York: Perseus Books Group.

Florida, R. (2017) The New Urban Crisis: Gentrification, Housing Bubbles, Growing Inequality, and What We Can Do About It. London: Oneworld Publications.

Gibson, C., Waitt, G., Walmsley, J. and Connell, J. (2010) 'Cultural festivals and economic development in nonmetropolitan Australia', Journal of Planning Education and Research, 29(3): 280-293.

Gibson, C. and Warren, A. (2014) 'Making surfboards: Emergence of a trans-Pacific cultural industry'. The Journal of Pacific History, 49(1): 1-25.

Gilmore, A. (2013) 'Cold spots, crap towns and cultural deserts: The role of place and geography in cultural participation and creative place-making', Cultural Trends, 22(2): 86-96.

Gregson, N., Crang, M., Ahamed, F., Akhter, N. and Ferdous, R. (2010) 'Following things of rubbish value: End-of-life ships, "chock-chocky" furniture and the Bangladeshi middle class consumer', Geoforum, 41(6): 846-854.

Hackney, F. (2013) 'Quiet activism and the new amateur: the power of home and hobby crafts', Design and Culture: The Journal of the Design Studies Forum, 5(2): 169-193

Hallam, E. and Ingold, T. (2007) 'Creativity and cultural improvisation: an introduction', in E. Hallam and T. Ingold (eds), Creativity and Cultural Improvisation London: Routledge.

Hargreaves, I. and Hartley, J. (eds) (2016) The Creative Citizen Unbound: How Social Media and DIY Culture Contribute to Democracy, Communities and the Creative Economy, Bristol: Policy Press.

Hawkins, H. and Price, L. (eds) (2018) Geographies of Making, Craft and Creativity, London: Routledge

Hecker, T. (2010) 'The slum pastoral: helicopter visuality and Koolhaas's Lagos', in Space and Culture, 13(3): 256- 269.

Holmes, H. (2015) 'Transient craft: reclaiming the contemporary craft worker', Work, employment and society, 29(3): 479-495.

Jackson, I. (2002) 'Politicised territory: Nek Chand's Rock Garden in Chandigarh', Global Built Environment Review, 2(2): 51-68.

Jakob, D. and Thomas, N. (2017) 'Firing up craft capital: the renaissance of craft and craft policy in the United Kingdom'. International Journal of Cultural Policy, 23(4): 495511 
Landry, C. (2000) The Creative City. A Toolkit for Urban Innovators, London: Earthscan.

Lee, J. (2010) Home life: cultivating a domestic aesthetic. Contemporary Aesthetics, 8. DOI: $\underline{\text { http://hdl.handle.net/2027/spo.7523862.0008.015 }}$

Literat, I. and Glăveanu, V.P. (2016) 'Same but different? distributed creativity in the internet age'. Creativity: Theories-Research-Applications, 3(2): 330-342.

Lobo, M. (2017) 'Re-framing the creative city: Fragile friendships and affective art spaces in Darwin, Australia', Urban Studies, https://doi.org/10.1177/0042098016686510

Lydon, M. and Garcia, A. (2015) Tactical Urbanism: Short-term Action for Long-term Washington: Change Island Press.

McFarlane, C. (2011) 'The city as assemblage: dwelling and urban space', Environment and Planning D: Society and Space, 29(4): 649-671

Mehrotra, R. (2008) 'Negotiating the static and kinetic cities: the emergent urbanism of Mumbai', in A.Huyssen (ed) Other Cities, Other Worlds: Urban Imaginaries in a Globalizing Age, Durham, NC: Duke.

Miles, A. and Ebrey, J. (2017) 'The village in the city: participation and cultural value on the urban periphery', Cultural Trends, 26(1): 58-69

Mommaas, H. (2004) 'Cultural clusters and the post-industrial city: towards the remapping of urban cultural policy', Urban Studies, 41(3): 507-532.

Mould, O. (2014) 'Tactical urbanism: the new vernacular of the creative city', Geography Compass. 8(8): 529-539,

Ocejo, R. (2012) 'At your service: The meanings and practices of contemporary bartenders', European Journal of Cultural Studies, 15(5): 642-658.

Platt, L. (2017) 'Crafting place: Women's everyday creativity in placemaking processes', European Journal of Cultural Studies DOI: 10.1177/1367549417722090

Price, L. (2015) 'Knitting and the city', Geography Compass, 9(2): 81-95.

Rautio, P. (2009) 'On hanging laundry: the place of beauty in managing everyday life,' Contemporary Aesthetics 7 DOI: http://hdl.handle.net/2027/spo.7523862.0007.007

Robinson, J. (2006) The Ordinary City: Between Modernity and Development, London: Routledge.

Vannini, P. and Taggart, J. (2014) 'Do-it-yourself or do-it-with? The regenerative life skills of off-grid home builders', Cultural Geographies, 21(2): 267-285. 
Vásquez, C. and Creel, S. (2017) 'Conviviality through creativity: Appealing to the reblog in Tumblr Chat posts', Discourse, Context \& Media, 20: 59-69.

Vich, V. (2004) 'Popular capitalism and subalternity: street comedians in Lima' Social Text 81, 22(4): 47-64.

Warren, A. and Gibson, C. (2011) 'Blue-collar creativity: reframing custom-car culture in the imperilled industrial city', Environment and Planning A, 43(11), pp.2705-2722.

Waitt, G. and Gibson, C. (2013) 'The Spiral Gallery: non-market creativity and belonging in an Australian country town'. Journal of Rural Studies, 30: 75-85.

Wendler, J. (2016) 'Grassroots experimentation: alternative learning and innovation in the Prinzessinnengarten, Berlin', in Evans, J., Karvonen, A. and Raven, R. eds., The Experimental City, London: Routledge., pp.150-162 